\title{
Feminist Reflections on Humans and Other Domestic Animals
}

Dianne Romain

Sonoma State University

Editors' Note: The following paper by

Professor Romain, and the commentary

on it by Professor Rud, were presented

at the Eastern Division meetings of the

Society for the Study of Ethles and

Animals, held In Atlanta, Georgla,

December, 1989.

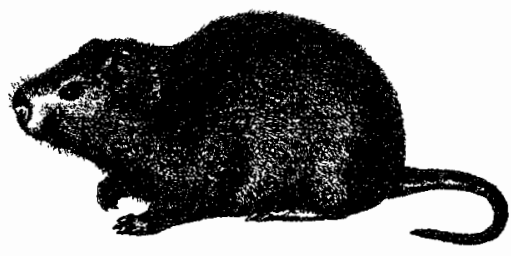

A friend once told me about the cows corralled in a nearby pasture. Once a year men come to take away their calves. "Afterward the cows moo for four days and nights," she said.

I myself know what a distressed moo sounds like. And now when I hear it coming across the fields I think of mother cows losing their calves. When I hold the image of the mother cow in my mind against the remembrance of my mother's pot roast, the mother cow wins. When I recall the cow's cries, I cannot imagine accepting my mother's offer.

Why do I call this writing "feminist reflections?" First, I am practicing a common feminist methodology: raising consciousness through storytelling. Second, in my reflections I focus on feminist thought to articulate some problems with my relations to other domestic animals. I use the work of feminist writers to discuss caring, oppression, and spirituality. I use the word "reflections" to suggest that I am not trying to establish or prove a particular thesis. ${ }^{1}$ I intend my observations to raise questions, rather than answer them.

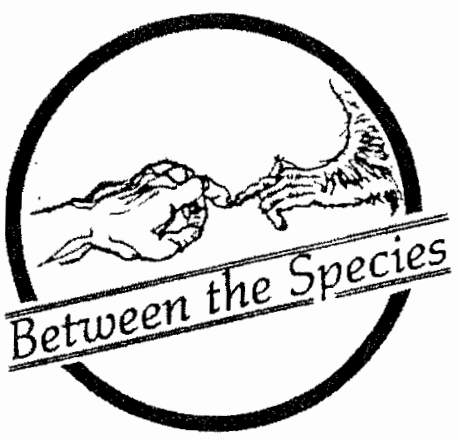

Napenthe

I took Napenthe from her family when she was a kitten. Her "owner" sold her to me. Napenthe stayed in the closet of my studio apartment for two days, then accepted me as her companion. For years I lived alone, and she had my full attention. She curled up beside me whenever she chose, though I pushed her away when she tried to come between me and a book. Every night Napenthe crawled in under the covers beside me.

When we moved in with my love, he didn't want Napenthe in the bedroom at night. "You cuddle her instead of me," he said. And so we shut the bedroom door against Napenthe. When she cried, as only a Siamese can, and woke us up, we confined her downstairs near her next favorite resting place, the top of the hot water heater.

In the morning or if I've been away for the day, Napenthe follows me closely and meows in her most complaining tone until I pick her up. She snuggles against my neck, rubs her nose against my ear for a few minutes, then when I put her down, she goes back to the hot water heater or under the wood stove. But sometimes when I'm in a moming rush or cranky after a day at school, I brush her off.

Cats like animal contact. When ours are allowed in the bedroom in the morning, all three snuggle up against

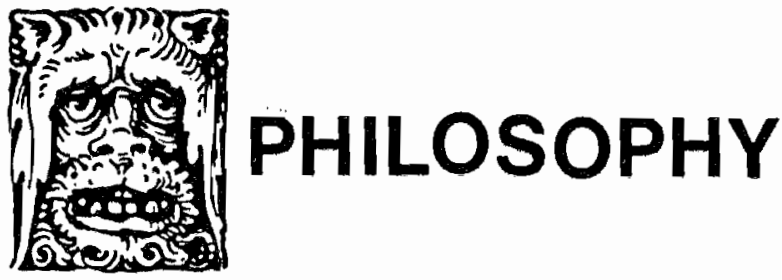


me. Mutley kneads the blanket over my chest, Napenthe washes my ears, and Turtle licks my hand. But my cats never feel a coarse tongue against their own ears. Raised away from each other, they do not sleep together or groom each other the way littermates $\mathrm{do}^{2}$

\section{Caring with Cats}

In her book, Caring: A Feminine Approach to Ethics and Moral Education, Nell Noddings places caring and the commitment to sustain it at the "universal heart" of her ethic. ${ }^{3}$ Her paradigm of caring is a human nother's engrossment in her child. She writes,

The caring of mother for child, of human adult for human infant, elicits the tenderest feelings in most of us. Indeed, for many women this feeling of nurturance lies at the very heart of what we assess to be good. ${ }^{4}$

Though Noddings allows that other animals care and can respond to human care, human obligations to care extend primarily to other humans. She writes, "A philosophical position that has difficulty distinguishing between our obligation to human infants and, say, pigs is in some difficulty straight off. It violates our most deeply cherished feeling about human goodness." For Noddings, my obligation to care is limited by the nature of my potential relationship with the one I would care for; I have an obligation to care only if a potential for mutual response exists. Noddings believes that whereas human children have potential for mutual response, other animals can never respond mutually. ${ }^{5}$ Thus, my obligations to nonhuman animals are limited.

Now, there are notorious problems with Noddings' view that obligation derives from mutual response. It rules out obligations to distant humans, as well as obligations to animals and the environment. Nonetheless, Noddings' ethical ideal has some good results for animals. Her recognition that other animals care and her placement of caring as an ideal entail that caregiving nonhuman animals are valuable, regardless of their usefulness to humans. If I had thought as much about Napenthe's needs as my own and if I had valued caring relationships between cats, I would have left Napenthe with her family or adopted her siblings. Then she would have family members to lick her ears and keep her warm at night. ${ }^{6}$

\section{Morality in Human Terms}

One day when driving along a freeway cut through the hills of Sonoma County in Northern California, I listened to a woman-a self-described animal psychictalking about animals raised for slaughter. In the background I heard the sounds of a slaughterhouse. In her soft, reassuring voice, the woman said she'd gone to the slaughterhouse to determine for herself how cattle felt about their lives. She described the slaughterhouse process step by step. She said the cattle did not experience extensive pain. She said the cattle said they were satisfied with their lives, for they understood they were giving up their lives for a good purpose. The interviewer asked a man working at the slaughterhouse what he thought. This country man, who'd been at the slaughterhouse working daily with the cattle, replied that he didn't know what the cows thought.

I present this example to warn that closeness is no guarantee of enlightenment, nor for that matter is engrossment. I've never been to a slaughterhouse, so I can't compare my experience with this woman's. But I felt sick listening to her. Her statement reminded me of hearing women described as satisfied in their service roles. But throughout history, oppressed people have put on a good face to service to avoid social, economic, or physical reprisals. ${ }^{7}$ Thus before we can use an oppressed person's voice to justify our actions, we need to look at whether she is speaking freely. In the case of beings who do not share a language, more difficulties arise. Here it's not just a question of being aware of a faise voice but of trying to imagine how the being would describe her good, if she could. In making this determination we need to be wary of human bias. We need to consider whether one who benefits from a cow's service can honestly judge the cow's own good.

Humans are often not to be trusted in judging a cow's good, nor in judging a cow's value. In determining value, philosophers such as Aristotle, Kant, Mill, Bentham, and Noddings, begin with humans. They treat man and, more recently, woman as the measure of all things. Other animals come off best with Bentham, but even so their intrinsic value diminishes as their ability to experience pleasure and pain diminishes.

But leaving aside for the moment the question of human presumption, there is another problem for humans in assessing animal welfare. How can we recognize the deprivation of other animals, when we do not see our own? I sit in my study, no longer feeling 
the paper under my hand. I click, click, click on the keyboard of my computer. I teach under fluorescent lights in rooms that have no windows. Two weeks after the switch to daylight savings time I am still surprised when I come from my evening class to find it light outside. It could have been midnight or noon. My classroom does not show the difference. Is it any wonder that, in my separation from nature, I don't worry over removing animals from their natural habitats? Do family-room toucans miss the damp smell of tropical forests and the cries of howler monkeys? How could I have such thoughts without raging over my own domestication? But from my human point of view, forced air heating and fluorescent lights are progress. The toucan is lucky to share my room with me.

\section{Oppression}

I've talked about humans oppressing other animals. But I wonder in what sense the concept "oppression" applies. When feminists talk of the oppression of women, we focus on the absence of women from positions of political and economic power. We describe the societal attitudes ingrained in us to keep us politically and economically powerless. But surely other animals do not seek senate seats and equal pay for equal work. With other animals should we then think in terms of suffering, rather than of oppression?

Marilyn Frye's article, "Oppression," suggests an answer to this question. Though Frye focuses on the oppression of women, her analysis can be extended to other animals. She writes:

[I]t is clear that if one wants to determine whether a particular suffering, harm or limitation is part of someone's being oppressed, one has to look at it in context in order to tell whether it is an element in an oppressive structure: one has to see if it is part of an enclosing structure of forces and barriers which tends to the immobilization and reduction of a group or category of people. One has to look at how the barrier or force fits with others and to whose benefit or detriment it works. ${ }^{8}$

Frye's analysis of oppression applies to domestic animals. Humans create social forces and barriers which limit cows and cats. Domestication itself limits cow and cat behavior. But cows and cats are further controlled for human purposes. Scratching cats are declawed. Cows are forced to join the milk producing work force. Humans limit cow and cat behavior for human ends.

I add another feature to oppression. The oppressor justifies suffering and control by appealing to the oppressor's greater value. This feature of oppression highlights a difference between the way humans and nonhumans experience oppression: humans experience not only the pain of confinement but also the humiliation of being undervalued. Other oppressed animals don't have the additional pain of recognizing that humans devalue them. But other animals are undervalued, caused pain, and controlled for our benefit and to their detriment. Thus, other animals are oppressed.

\section{Seeing God}

My description of human oppression of other animals presupposes that humans are not more valuable than animals. I do not know how to establish this assumption. But then neither has anyone established the alternative, that humans are intrinsically more valuable than other animals. I can't tell you how I know my assumption to be true. But I can tell you something about how I came to accept it, or I should say, how I came to try it on. For I'm not sure I do fully accept it.

When I was a child I lay awake at night anguishing about going to hell. I was worried because I didn't know how to believe in God, and I had been told I would go to hell if I didn't believe. Eventually I solved my problem by giving up my belief in hell. Though I sometimes felt I missed something by not believing in a spiritual world, I never wanted to believe in a God I had come to associate with oppression and violence. But then I began to think I could believe in God after all, when I read Alice Walker's The Color Purple. Here's how Shug describes how she found God:

My first step from the old white man was trees. Then air. Then birds. Then other people. But one day when I was sitting quiet and feeling like a motherless child, which I was, it come to me: that feeling of being part of everything, not separate at all. I knew that if I cut a tree, my arm would bleed. And I laughed and I cried and I run all around the 
house. I knew just what it was. In fact, when it happen, you can't miss it.?

But how does one take the first step? How does one see the trees as sacred? Or the air? or birds? Celie reports what Shug says:

Still, it like Shug say, You have to git man off your eyeball, before you can see anything a'tall.

Man corrupt everything, say Shug. He on your box of grits, in your head, and all over the radio. He try to make you think he everywhere. Soon as you think he everywhere, you think he God. But he ain't. Whenever you trying to pray, and man plop himself on the other end of it, tell him to get lost, say Shug. Conjure up flowers, wind, water, a big rock. ${ }^{10}$

Long after I gave up my belief in hell, I still had man on my eyeball. I had used man as the determination of value. I valued myself to the extent I had traits like those traditionally associated with men. More recently, through the work of feminist writers like Noddings and Carol Gilligan, I added woman to my eyeball. Now I'm trying to remove both man and woman from my eyeball, so I can see the value in other animals. ${ }^{11}$

\section{The Yellow Tom and Old Grey}

He came running when I called, al though I had never called him before. I hadn't wanted to encourage him. But when I finally called him, he nuzzled up against $m e$, as if he' $d$ been waiting his whole life. He got away once from the cat carrier. My stepson, who was standing nearby, said, "You'll never capture him now." "He will come to me," I said. I could see the cat was so starved for care that he would come, and he did. He came out from under the porch when I called, and that time I was able to lock him in the carrier.

I still wonder at myself. How could I have taken him to the animal shelter after witnessing his need? On the way to the shelter I became more and more distressed. But I reminded myself that the tom had been chasing and attacking our female cats, that one of them was pregnant and he might kill her kittens, that he was spraying all around our house. With these justifications I could still not go into the shelter, until I decided to adopt another cat in his place. And so I got Mutley.
Now there's a stray grey tom. When we're asleep or gone, he comes in through the upstairs cat door, eats the cat food, sprays, and leaves again. My love says, "In the old days, I would have shot him." The old days are gone. My love put a door at the bottom of the stairway to keep Old Grey from spraying on the new rug. But the tom still routinely perfumes my study. Our veterinarian says we should get rid of him. She suggests we rent a Havahart trap. But I'm reluctant. What has he done after all? Our cats don't seem to mind him, and we have no kittens to protect. He could catch and carry rabies, but then so, too, could the skunks, and I'm not considering trapping them. I haven't forgotten how I felt when I took the yellow tom to the animal shelter. I think I can live with Old Grey's spray.

\section{Ideals and Reality}

How can I say what I say and still act as I do? ${ }^{12}$ If I really believed that humans are not more valuable than other animals, would I even think about trapping Old Grey? I suppose I could be more generous to myself and ask instead, if I hadn't considered the value of Old Grey, would I even have considered not trapping him? But I want to focus now on how I am limited by the behavior of other humans.

I wouldn't have had to decide how to respond to Old Grey, if some other human had not made a pet out of him and then abandoned him. My predicament flows from the activities of other humans. I wish I could put him back on their doorstep. But I can't. I don't know who they are. And if I did, they'd probably just drop him in the country again or take him to the animal shelter.

Ultimately my predicament with Old Grey stems from the domestication of animals. If he were a wild cat and not a pet, he'd stay in the woods like the bobcats. If I didn't have other domesticated female cats in my house, he would not come in to spray. But Old Grey's a thoroughly domesticated animal, and I do have three female cats. Naturally, he's going to visit.

I wonder if I' $d$ be better off without domesticated animals. I wouldn't have the trouble with Old Grey. But then I wouldn't have my litule love slave, Napenthe, either. In spite of my complaints about her scratchy tongue, I profit from her domesticated purr. I wonder whether I would end the domestication of other animals, if I could. But even this proposal is subject to human bias, because I cannot communicate with other animals to see what they would choose for themselves. 


\section{Rosella}

One October morning everal years ago an escapee parrot, An Australian Rosella, appeared on a lower limb of a Doug. Fir tree in our yard. She woke us up with her loud joyous calls.

We went to the local feed store and purchased seeds for her, then placed a feeder in the walnut tree close to our house, so we could watch her. Soon she came to the walnut tree every morning and looked at the front door until I brought the seeds out. She flew off to the fir until I left again, then she flew back and ate her breakfast. When she was finished, other birds would fill the tree and soon empty the feeder.

Rosella, as we called her, would stay for a while on the lower fir limb and sometimes climb down the wire fence and walk around in the yard. After her morning visit she would swoop across the blackberry pasture to the Monterey Cypress lining the top of our hill. As she flew, she would sing a different song from the one that roused us in the moming. Typically, Rosella came back again in the late afternoon for a short visit, then went off until the morning feeding. This went on for six months. She even survived pea-sized hail and light snow.

One March day Rosella didn't return. We'd talked about capturing her-for her own good, of course-to protect her from the wind and rain and from predators: the cats, the owls. But we never did try very hard to find a way to capture her. There would have been no magic in a caged Rosella waiting for her morning sunflower seeds. Even if she had continued with the full range of her songs, we wouldn't be able to watch her swoop across the blackberries.

\section{Diminished Relations/Expanded Relations}

I had questioned caging birds before I knew Rosella. But after hearing her sing above the blackberries, I could never keep a bird in a cage. I don't think anyone would want a bird in a cage if they had known Rosella. To get even a glimpse of a freed pet gives one a new ideal.

The trick is to get this experience. It's the same with human relations. If you're lucky enough to experience a relationship in which there's mutual caring and respect, you'll never be satisfied with less. But because humans are often raised with models of abuse of power, mutual caring and respect seems a romanticized ideal rather than a realizable goal. It was only after years of psychoanalysis that I learned to expect mutual caring and respect. Now I accept nothing less. I suspect the same is true of us and other animals. We would not want to go back, if we ever gave up oppressive relations with them. But it's hard to see this now, for in the existing world oppressive relations between humans and other animals are the norm.

\section{Lingering Doubts}

Whenever I assign papers on controversial topics, I ask the students to come to a conclusion, but also to express their lingering doubts. There's something liberating about this exercise. One needn't have final answers before offering a conclusion. In writing this essay I've allowed myself to make a claim that might otherwise strike me as wild, because I knew I'd have the opportunity to express my lingering doubts. I'm not really doubtful about my suggestion that we remove man from our eyeballs, that is, that we stop using humans as the measure of all things. I think we should give this a try. But I'm anxious about what we'll find. Will we judge a cat to have equal importance to a child? What will this mean for how we treat cats and children? I don't know how to begin answering these questions, and so I leave them as lingering doubts. But though I find these doubts disturbing, I am not yet ready to take back my suggestion. I suspect humans need to reconsider their place in the world, and my suggestion is one way to begin.

\section{A Cow on Vacation}

There's one more story I want to tell. A few days ago I was driving back from the coast when I saw a cow with an udder ballooning almost to the ground. The rest of the herd moved up the hillside as they grazed. She lagged behind, moving slowly, her hind legs straddling her enormous udder. But still she moved toward the others. I pulled over, turned around, and drove back so my love could see her. Then we started looking for the farmer. I thought she was ill or that someone had forgotten to milk her. I was afraid she would burst.

We found a farmer a few miles up the road. She wasn't his cow, but he'd had others like her. He told us calves grow two-thirds of their size in the last two months of pregnancy. Dairy farmers stop milking pregnant cows for those two months, so the cow will 
have plenty of nutrition for the calf. "We call it "going on vacation," the farmer said.

"But are you sure she's all right?" I asked and described again how she looked.

"That's the way they get, especially the older ones," he said.. "Her udder will start shrinking again in about a week."

I haven't been able to get the image of that cow out of my head. I wish I could. Whenever I think of ice cream, cheese, and calcium, I see her struggling to follow the others up the hill.

\section{Serious Wrongs}

"How can you think about cats and cows, when women still do not have political and economic equality?" This thought keeps coming to me. It echoes another thought, "How can you think about women's equality, when Nicaraguans are being killed in your name?"

Don't these very questions presuppose the superiority of human suffering? Perhaps I should just ignore them. But even if I accept the full worth of nonhuman animal suffering, I would still want to think about the suffering of women and Nicaraguans. Since time is short, I would like to find ways of integrating my concerns. Some connections come to mind. I think of my love saying, "In other days, I would have shot the tom." He would have killed a cat to protect me from its spray. Another friend tells me of her Illinois father. Frightened family women called him in from the fields to kill harmless snakes. Through killing an animal this man "prolects" the women. Men and women who practice these roles reinforce the power structure that keeps women and other animals oppressed. The woman seems helpless without the man, even with a harmless snake or cat. From early on women allow and even invite men to kill in our names. And so when our government tells us that Nicaragua is dangerous, are not many women inclined to leave Nicaragua to the men, too?

As one who wants to stop oppression in all its forms, I find it useful to study a system of oppression in which I am not a victim. By looking at my relations with domestic animals I see how I benefit from oppression. And I see the ties that bind me to oppression. I cannot simply give up role as oppressor unless the system of domesticity changes. But though I cannot singlehandedly end systems of oppression, that should not stop me from describing them and the suffering they bring to their victims, whether human or cat.

\section{Notes}

I am grateful to Pat Demery, Sterling Bennett, and Philip O. Temko for their comments on earlier versions of this essay.

1 My methodology was inspired by Joyce Trebilcot, "Dyke Methods," Hypatia 3 (Summer 1988): 1-13

2 For a story about a lonely horse, see Alice Walker, "Am I Blue?" in Irene Zahava, Through Other Eyes: Animal Stories by Women (Freedom, California: The Crossing Press, 1988): 1-6.

3 Nell Noddings, Caring: A Feminine Approach to Ethics and Moral Education (Berkeley: University of California Press, 1984): 5.

4 Ibid. 87.

5 Ibid.

6 Mutley was already removed from her family when I got her from the animal shelter. Turtle was one of a pile of abandoned kittens I found on the country road near my home. On my way home from school one foggy evening I saw them huddled together in the middle of the road, as if waiting for whoever dropped them off to come back. We gave away two of the kittens, Myrtle, Turtle's other littermate, died several years later.

7 Marilyn Frye, "Oppression," in The Politics of Reality: Essays in Feminist Theory (Trumansberg, N.Y.: The Crossing Press, 1983): 1-16.

8 Ibid., 10-11.

9 Alice Walker, The Color Purple (New York: Washington Square Press, 1982): 178.

10 Ibid., 179.

11 Shug's view of God also entails that I would find value in the woods, in the waters, and in the earth itself. But for the purpose of this paper, I will not discuss these further implications.

12 For more thoughts about ideals and action, see Ellen Bring, "Moving Towards Coexistence: An Interview with Alice Walker," in The Animals' Agenda (April 1988): 6 ff. 